\title{
Injuries of Three Health Care Districts Employees in Finland ${ }^{*}$
}

\author{
Simo Salminen, Annika Parantainen ${ }^{\#}$ \\ Finnish Institute of Occupational Health, Helsinki, Finland \\ Email: simo.salminen@ttl.fi, "annika.parantainen@ttl.fi
}

Received May 11, 2012; revised June 22, 2012; accepted July 3, 2012

\begin{abstract}
Occupational injuries in hospitals have two-fold effects, decreasing both safety employees and the level of patient care. The aim of this study is to examine occupational injuries in Finnish hospitals. Three health care districts reported injuries and violent acts and the number of their employees over a period of three years: 2006-2008. Every eighth hospital worker was involved in an occupational injury each year, which is more than among the general working population. In addition, every twentieth hospital employee had encountered violence or a threat of violence in their work, which corresponds to the risk of violence among working men. There were huge differences in injury and violence rates between health care districts, which were due to different reporting procedures used in districts. Underreporting is another possible explanatory factor especially for minor injuries and verbal aggression.
\end{abstract}

Keywords: Occupational Injuries; Violence; Health Care

\section{Introduction}

Occupational injuries in hospitals have two-fold effects. First, they decrease the safety of employees. Secondly, they also decrease the level of patient care, when other employees have to cover the work of the injured worker. In this way, occupational safety can become a critical issue for patient safety. The aim of this study was to examine occupational injuries in Finnish hospitals. As far as we know, there are no previous publications regarding the injuries of Finnish hospital employees.

In the United States, the most frequent injuries in hospitals were overexertion, slips, contact with objects, falls, and assaults [1,2]. Falls were the leading cause of occupational injury among health care workers, and facility support workers were at the highest risk of falling in hospitals [3]. The most frequent overexertion injury occurred during patient transfer to or from a bed [4]. Younger nurses in particular were prone to overexertion injuries [5].

Needle stick injuries were common, but minor. They were the most frequent injury type in a teaching hospital in Midwestern [6] and in a university hospital in Brazil [7]. Procedures involving intravenous catheters had the highest needle stick injury rate in a university hospital in Taiwan [8] and in Virginia [9]. However, needle stick injuries may have severe consequences, such as the hepatitis B virus, hepatitis C virus and human immuno-

*This work was supported by the Finnish Work Environment Fund.

\#Corresponding author. deficiency virus (HIV) [10]. Depression and anxiety were also possible psychological reactions to needle stick injury [11]. Health care workers with over 10 years experience at work had the highest risk of needle stick and sharps injuries [12,13].

Violence is another work safety problem in hospitals. One out of five European nurses had been a victim of patient violence [14]. In Michigan, three out of four emergency physicians had been verbally threatened, and one out of four had been a victim of physical assault [15]. In Japan, $24 \%$ of physicians had experienced verbal violence, and $2 \%$ physical violence at their work [16]. Physical violence mainly occurred in nursing homes, and in intensive care, psychiatric and emergency departments in Minnesota [17]. Nurses in emergency departments most often felt unsafe due to violence [18]. Younger age [19], female gender [20], shorter tenure [21] and lack of formal professional education [22] were risk factors of physical violence. Patients were most often the perpetrators [23], whereas in the American hospitals workeron-worker violence exceeded patient-to-worker violence [24].

\section{Methods}

The three districts reported injuries and violent acts over a period of three years: 2006-2008. Three years was selected as the follow-up period, as the number of injuries was sufficient and the effects of random factors related to one year do not determine the results. The health care 
districts also reported their number of employees per year and the sum of three years was used in Tables 1 and 3. A health district consists of one bigger central hospital and several smaller hospitals in the certain geographical area. All hospitals in the health districts were public ones. The number of employees in these three health districts represented $14 \%$ of the all employees in Finnish hospitals.

The health care districts reported the occupational injuries and violent acts against their employees. One district (A) sent the list of injuries that their insurance company had collected. Two other districts used their own reporting system and sent a list of injuries based on this information. The sum of three years' injuries and violent acts were used in Tables $\mathbf{1}$ and $\mathbf{2}$.

\section{Results}

The three health care districts reported a total of 3776 occupational injuries to their employees during 20062008. The total work years of the employees in these districts were 31,504 years, and the accident frequency (accidents per 1000 work years) was 119.9.

There were huge differences between health care districts in injury frequency (Table 1). The frequency reported by district $\mathrm{B}$ was seven times higher than that of district $\mathrm{A}$. The frequency of district $\mathrm{C}$ was near that of

\section{district B.}

These injuries caused altogether 10,055 absence days, which means an average of 9.1 days per injury. The most serious injuries occurred in district $C$, where injuries caused an average of 17.6 sick days. In district $\mathrm{B}$, the average was 8.7 days and in district A 4.5 days.

Figure 1 presents occupational injuries by injury type in 2006-2008 in all the three health districts. Needle stick injuries were the most common, and made up one fourth

Table 1. Occupational injuries in health districts.

\begin{tabular}{cccc}
\hline Health districts & $\mathrm{A}$ & $\mathrm{B}$ & $\mathrm{C}$ \\
\hline $\begin{array}{c}\text { Occupational } \\
\text { injuries }\end{array}$ & 100 & 2585 & 1091 \\
$\begin{array}{c}\text { Work years } \\
\text { Frequency } \\
\text { (acts/years) }\end{array}$ & 4511 & 18,560 & 8433 \\
\hline
\end{tabular}

Table 2. Violence in different health districts.

\begin{tabular}{cccc}
\hline Health districts & A & B & C \\
\hline $\begin{array}{c}\text { Occupational } \\
\text { injuries }\end{array}$ & 211 & 564 & 1054 \\
$\begin{array}{c}\text { Work years } \\
\text { Frequency } \\
\text { (acts/years) }\end{array}$ & 4511 & 18,560 & 8433 \\
\hline
\end{tabular}

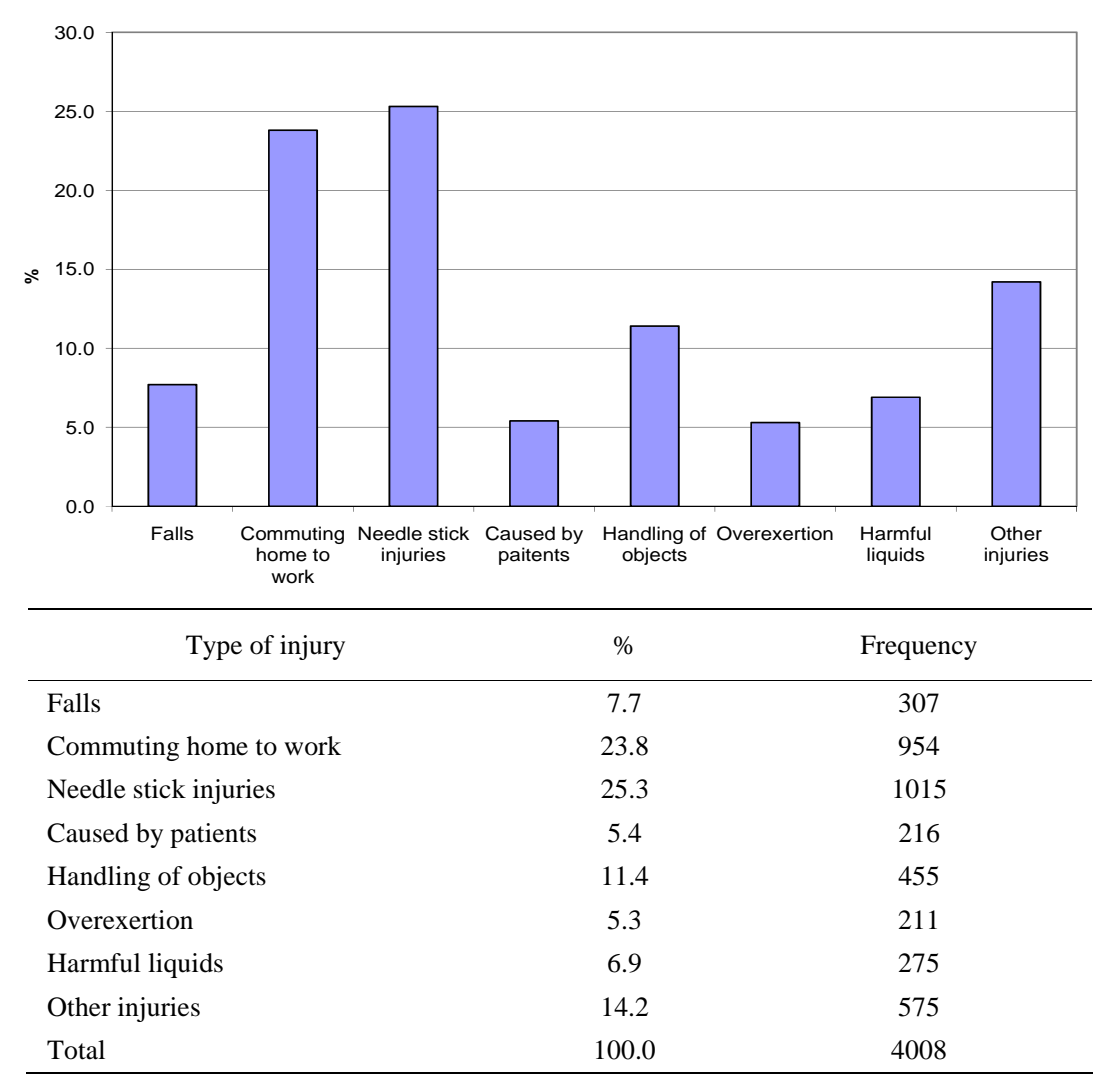

Figure 1. Occupational injuries by type. 
of occupational injuries. Over half $(54 \%, \mathrm{~N}=548)$ of needle stick injuries occurred among nurses, and 13\% (N = 132) among physicians. The other quarter of injuries occurred on the way to or from work (commuting). One out of ten injuries occurred while handling objects, including being struck by objects. Falls included both falls on the same level or to a lower level. Harmful liquids refer to all liquids or biological splashes that can cause skin disorders. Injuries caused by patients were, for instance, injuries caused by lifting a patient. Five percent of injuries were caused by overexertion, including strains, sudden moves, and lifting. The "other injuries" category included all other injuries.

The employees of the three health care districts encountered violence or threats of violence (verbal aggression) 1618 times. When this number was divided by the number of employees, the violence rate (violent acts per 1000 work years) was 51.4.

There were huge differences in violence at the workplace between health care districts (Table 2). The number of violent acts was the highest in district $\mathrm{B}$, whereas frequency was three times higher in district $C$ than in other districts. District A was situated between districts B and $\mathrm{C}$, although it was nearer B than C.

Verbal aggression was the most common type of violence (34\%, $\mathrm{N}=459)$ in hospitals, followed by, catching (27\%, $N=362)$, hitting (25\%, $N=343)$, and kicking $(14 \%, N=189)$.

\section{Discussion}

Our results show that the number of occupational injuries in Finnish hospitals was high. Every eighth hospital employee was involved in an occupational injury each year. This is more than in the Work and Health survey carried out by the Finnish Institute of Occupational Health, where every ninth respondent had been injured during the past 12 months [25].

The main limitation of this study is that health care districts used different methods to report injuries. One district (A) reported only those injuries, for which they have sent a compensation claim to the insurance company. Because in Finland companies can receive compensation from the fourth absence day of the injured worker, minor injuries were not always reported to the insurance company. The other districts have their own reporting systems, thus even minor injuries were registered. These differences between health districts reporting system partly explain the differences in injury rates. The different reporting systems made also the comparison of the three health districts not really meaningful.

Underreporting is one possible explanation for the huge differences between health care districts in accident frequency. Reporting of injuries decreased among American nurses if they felt a lack of concern for staff welfare from supervisors, or a climate of blaming employees [26].
The working conditions in different hospitals are almost same, and they did not explain the differences between health care districts.

Every twentieth employee in Finnish hospitals has encountered violence or a threat of violence in their work. This corresponds to the risk of violence among men in the Work and Health survey for the whole working population, whereas women in general experienced violence twice as often as hospital employees [25]. We assume that there was more violence in hospitals than this study showed, because employees did not report every violent act and especially verbal aggression, when they considered it part of everyday work [27]. Thus underreporting of violence in hospitals is possible.

Alcohol is an important contributing factor in violence against hospital employees. In the local hospital of a small Finnish city, every fourth new client in the emergency department was under the influence of alcohol on weekdays and as many as half on weekend nights [28]. In Australia, one third of patients who made threats in emergency departments were under the influence of alcohol [29].

Violence towards women increased in Finnish workplaces between 2003 and 2006 [30]. Almost half of the workplace violence towards women occurred in care settings [31]. The patient-health care provider relationship is the key to preventing violence in health care [32].

This study shows huge differences in violence at work between health care districts. A great variation between nursing units was also found in Australia [33]. Organizational factors may be behind these differences. Another explanation for the huge differences in injury and violence frequency between health care districts is the different reporting procedures used. Some districts used their own reporting systems, including all injuries and violent acts. Other districts reported only the injuries for which a compensation claim was made to the insurance company. When compensation was only paid from the fourth day of absence, these districts did not report minor injuries. For example, common minor injuries such as falls and needle stick injuries were not reported. In health district $\mathrm{A}$, needle stick injuries were not registered as occupational injuries until they were reported to the hospital hygienist.

In order to prevent injuries for hospital employees, several strategies were recommended. Ergonomic assessment could prevent musculoskeletal injuries related to patient's transfer in the bed or to or from the bed [4, 34]. Wearing cloves, not recapping used needles and proper disposal of sharp objects were the ways to prevent needle stick injuries [35].

\section{Acknowledgements}

We thank the work safety personnel of three health care 
districts for giving their injury information.

\section{REFERENCES}

[1] C. Perhats, V. Keough, J. Fogarty, N. L. Hughes, C. J. Kappelman, M. Scott and J. Moretz, "Non-Violence-Related Workplace Injuries among Emergency Nurses in the United States: Implications for Improving Safe Practice, Safe Care,” Journal of Emergency Nursing, 2011. doi:10.1016/j.jen.2011.06.005

[2] N. D. Brown and N. I. Thomas, "Exploring Variables among Medical Center Employees with Injuries,” AAOHN Journal, Vol. 51, No. 11, 2003, pp. 470-481.

[3] S. Drebit, S. Shajari, H. Alamgir, S. Yu and D. Keen, "Occupational and Environmental Risk Factors for Falls among Workers in the Healthcare Sector," Ergonomics, Vol. 53, No. 4, 2010, pp. 525-536. doi:10.1080/00140130903528178

[4] I. L. Engkvist, M. Hagberg, E. W. Hjelm, E. Menckel, L. Ekenvall and PROSA Study Group, "The Accident Process Preceding Overexertion Back Injuries in Nursing Personnel,” Scandinavian Journal of Work, Environment and Health, Vol. 24, No. 5, 1998, pp. 367-375. doi:10.5271/sjweh.357

[5] L. Laflamme, "Overexertion-Injury Types among Female Swedish Nurses and Nursing Auxiliaries: An Age-Related Problem?” Safety Science, Vol. 27, No. 2, 1997, pp. 129-139. doi:10.1016/S0925-7535(97)00075-1

[6] W. E. Wilkinson, “Occupational Injury at a Midwestern Health Science Center and Teaching Hospital,” AAOHN Journal, Vol. 35, No. 8, 1987, pp. 367-376.

[7] D. L. M. Pinho, C. M. Rodrigues and G. P. Gomes, "Perfil dos Acidentes de Trabalho No Hospital Universitario de Brasilia," Revista Brasileira de Enfermagem, Vol. 60, No. 1-4, 2007, pp. 291-294. doi:10.1590/S0034-71672007000300008

[8] L. J.-H. Lee, C.-T. Yu and J.-D. Wang, "Procedure-Specific Rates for Needlestick Injuries in Health Care Workers," Journal of Occupational Health, Vol. 43, 2001, pp. 278-280. doi:10.1539/joh.43.278

[9] J. Jagger, E. H. Hunt, J. Brand-Elnaggar and R. D. Pearson, "Rates of Needle-Stick Injury Caused by Various Devices in a University Hospital," New England Journal of Medicine, Vol. 319, 1988, pp. 284-288. doi:10.1056/NEJM198808043190506

[10] T. O’Connell and B. Hayes, “Occupational Sharps Injuries in a Dublin Teaching Hospital," Irish Medical Journal, Vol. 96, No. 5, 2003, pp. 143-145.

[11] J.-W. Sohn, B.-G. Kim, S.-H. Kim and C. Han, "Mental Health of Healthcare Workers Who Experience Needlestick and Sharps Injuries,” Journal of Occupational Health, Vol. 48, 2006, pp. 474-479. doi:10.1539/joh.48.474

[12] A. Martins, A. C. Coelho, M. Vieira, M. Matos and M. L. Pinto, “Age and Years in Practice as Factors Associated with Needlestick and Sharps Injuries among Health Care Workers in a Portuguese Hospital," Accident Analysis and Prevention, Vol. 47, 2012, pp. 11-15. doi:10.1016/j.aap.2012.01.011
[13] G. Kebede, M. Molla and H. R. Shrama, "Needle Stick and Sharps Injuries among Health Care Workers in Gondar City, Ethiopia," Safety Science, Vol. 50, No. 3, 2012, pp. 1093-1097. doi:10.1016/j.ssci.2011.11.017

[14] D. Camerino, M. Estryn-Behar, P. M. Conway, B. I. J. M. van Der Heijden and H.-M. Hasselhorn, "Work-Related Factors and Violence among Nursing Staff in the European NEXT Study: A Longitudinal Cohort Study,” International Journal of Nursing Studies, Vol. 45, No. 1, 2008, pp. 35-50. doi:10.1016/j.ijnurstu.2007.01.013

[15] T. Kowalenko, B. L. Walters, R. K. Khare and S. Compton, "Workplace Violence: A Survey of Emergency Physicians in the State of Michigan," Annals of Emergency Medicine, Vol. 46, No. 2, 2005, pp. 142-147. doi:10.1016/j.annemergmed.2004.10.010

[16] M. Arimatsu, K. Wada, T. Yoshikawa, S. Oda, H. Taniguchi, Y. Aizawa and T. Higashi, “An Epidemiological Study of Work-Related Violence Experienced by Physicians Who Graduated from a Medical School in Japan,” Journal of Occupational Health, Vol. 50, No. 4, 2008, pp. 357-361. doi:10.1539/joh.L7142

[17] S. G. Gerberich, T. R. Church, P. M. McGovern, H. E. Hansen, N. M. Nachreiner, M. S. Geisser, A. D. Ryan, S. J. Mongin and G. D. Watt, "An Epidemiological Study of the Magnitude and Consequences of Work Related Violence: The Minnesota Nurses' Study,” Occupational and Environmental Medicine, Vol. 61, 2004, pp. 495-503. doi:10.1136/oem.2003.007294

[18] S. M. Kansagra, S. R. Rao, A. F. Sullivan, J. A.Gordon, D. J. Magid, R. Kaushal, C. A. Camargo and D. Blumenthal, "A Survey of Workplace Violence across 65 US Emergency Departments," Academy of Emergency Medicine, Vol. 15, 2008, pp. 1-7. doi:10.1111/j.1553-2712.2008.00282.x

[19] C. Kamchuchat, V. Chongsuvivatwong, S. Oncheunjit, T. W. Yip and R. Sangthong, "Workplace Violence Directed at Nursing Staff at a General Hospital in Southern Thailand,” Journal of Occupational Health, Vol. 50, 2008, pp. 201-217. doi:10.1539/joh.O7001

[20] W.-C. Chen, Y.-H. Sun, T.-H. Lan and H.-J. Chiu, "Incidence and Risk Factors of Workplace Violence on Nursing Staffs Caring for Chronic Psychiatric Patients in Taiwan,” International Journal of Environmental Research and Public Health, Vol. 6, No. 11, 2009, pp. 2812-2821. doi:10.3390/ijerph6112812

[21] R. L. Rodriguez-Acosta, D. J. Myers, D. B. Richardson, H. J. Lipscomb, J. C. Chen and J. M. Dement, "Physical Assault among Nursing Staff Employed in Acute Care," Work, Vol. 35, No. 2, 2010, pp. 191-200.

[22] L. B. Augestad and L. J. Vatten, "Five Year Risk of Assault on Employees in a Psychiatric Hospital,” Safety Science, Vol. 18, 1994, pp. 113-124. doi:10.1016/0925-7535(94)90020-5

[23] D. Hegney, A. Tuckett, D. Parker and R. M. Eley, "Workplace Violence: Differences in Perceptions of Nursing Work between Those Exposed and Those Not Exposed: A Cross-Sector Analysis,” International Journal of Nursing Practice, Vol. 16, No. 2, 2010, pp. 188-202. doi:10.1111/j.1440-172X.2010.01829.X 
[24] J. E. Arnetz, D. Aranyos, J. Ager and M. J. Upfal, “Development and Application of a Population-Based System for Workplace Violence Surveillance in Hospitals,” American Journal of Industrial Medicine, Vol. 54, No. 12, 2011, pp. 925-934. doi:10.1002/ajim.20984

[25] R. Grönqvist, S. Mattila and S. Salminen, ”Työtapaturmat (Occupational Injuries),” In: T. Kauppinen, et al., Eds., Työja Terveys Suomessa 2009, Työterveyslaitos, Helsinki, 2010, pp. 109-117 (in Finnish).

[26] J. G. Brown, A. Trinkoff, K. Rempher, K. McPhaul, B. Brady, J. Lipscomb and C. Muntaner, "Nurses’ Inclination to Report Work-Related Injuries,” AAOHN Journal, Vol. 53, No. 5, 2005, pp. 213-217.

[27] R. Chapman, L. Perry, I. Styles and S. Combs, "Consequences of Workplace Violence Directed at Nurses," British Journal of Nursing, Vol. 18, No. 20, 2009, pp. 12561261.

[28] I. Nurmi-Lüthje, P. Lüthje, K. Karjalainen, K. Salmio, J. Pelkonen, J. Hinkkurinen, L. Lundell, K.-M. Karjalainen and A. Virtanen, "Väkivallan Uhrit Aluesairaalan Päivystyspoliklinikassa-Etenevä Tutkimus (Victims of Violence at Emergence Department of Local Hospital-A Progressing Study),” Doudecim, Vol. 124, 2008, pp. 13811388.

[29] J. C. Knott, D. Bennett, J. Rawet and D. Mc. D. Taylor, "Epidemiology of Unarmed Threats in the Emergency Department,” Emergency Medicine of Australia, Vol. 17, 2005, pp. 351-358. doi:10.1111/j.1742-6723.2005.00756.x

[30] N. Hintikka and K. L. Saarela, "Accidents at Work Related to Violence-Analysis of Finnish National Accident Statistics Database,” Safety Science, Vol. 48, No. 4, 2010, pp. 517-525. doi:10.1016/j.ssci.2009.12.024

[31] M. Heiskanen, "Violence at Work in Finland; Trends, Contents, and Prevention,” Journal of Scandinavian Studies in Criminology and Crime Prevention, Vol. 8, No. 1, 2007, pp. 22-40. doi:10.1080/14043850701278473

[32] J. T. Wassell, "Workplace Violence Intervention Effectiveness: A Systematic Literature Review," Safety Science, Vol. 47, No. 8, 2009, pp. 1049-1055. doi:10.1016/j.ssci.2008.12.001

[33] M. Roche, D. Diers, C. Duffield and C. Catling-Paull, "Violence toward Nurses, the Work Environment, and Patient Outcomes," Journal of Nursing Scholarship, Vol. 42, No. 1, 2010, pp. 13-22. doi:10.1111/j.1547-5069.2009.01321.x

[34] K. Peled, "Workplace Safety Assessment and Injury Prevention in Hospital Settings,” Work, Vol. 25, No. 3, 2005, pp. 273-277.

[35] B. Shariati, A. Shahidzadeh-Mahani, T. Oveysi and H. Akhlaghi, "Accidental Exposure to Blood in Medical Interns of Tehran University of Medical Sciences,” Journal of Occupational Health, Vol. 49, 2007, pp. 317-321. doi:10.1539/joh.49.317 